\title{
Reducing your business rates
}

Paula Slinger

Practice Management Consultant

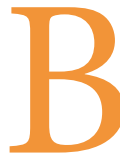

usiness owners are usually interested in finding ways to reduce business expenses and increase business related profit.

It can be quite confusing looking at the various deals and packages on offer from utility providers. But there is one expense you may be able to reduce considerably, business rates.

There are two ways to claim help with business rates. Either with the local council (which is recommended as the first choice to save the NHS money), or if you do not qualify for the government exemption, then there is the NHS reimbursement.

Claiming from your local authority will usually depend on a number of factors such as whether or not there are any local schemes running or whether you fall into certain eligible areas such as small business, the rateable value of your property, rural business, enterprise or even enterprise zones which potentially could offer $100 \%$ relief. Many businesses may be missing out on these entitlements by not knowing they are available. We always recommend checking with your council to be sure you are not missing an opportunity to claim what is rightfully yours.

The relief available to one practice may not always be available to another, which is why it is good to call your local council and discuss your position. Alternatively you can take a look at the Government website which is dedicated to business rate relief.

If you deliver NHS services, then you will need to ensure you can provide information about your NHS income. You may be asked to provide evidence of the percentage of NHS income against your private income. This is what is used to determine what help you are entitled to receive.

For practices based in England and Wales, the Statement of Financial Entitlements covers payments that a provider/performer is entitled to. In
Northern Ireland and in Scotland, you would find the information in the Statement of Renumeration.

To claim business rates as an NHS practice in England, Wales and Northern Ireland, for instance, you will need to say yes to the below two questions:

$\rightarrow$ Is the Contractor or one of the Partners a nondomestic rates payer?

$\rightarrow$ Is the total value of NHS dental services provided at the practice at least $£ 25,000$ ?

If the answer is yes, the amount you can claim would be based on the information below for your area. Scotland will base it on the gross earnings for the premises.

To claim you will need to have the relevant information to submit to your Local Health Authority:

$\rightarrow$ Evidence of Gross income and NHS percentage income

$\rightarrow$ The Demand Notice

$\rightarrow$ Receipt from the Council for the whole amount or, if the contractor pays in two instalments, half the amount specified in the Demand Notice

$\rightarrow$ If the contractor pays by monthly instalments

$\rightarrow$ Details of the amount to be paid each month

$\rightarrow$ Date payments are due to commence

$\rightarrow$ Date payments are due to cease

$\rightarrow$ To be reimbursed in lump sum after payment of all instalments - proof of payment of whole amount.

\section{England, Wales and Scotland}

The amount you can claim will depend on how much of your gross income relates to NHS incomes.

\section{Northern Ireland}

Like England, Wales and Scotland, what you can claim will depend on how much of your income is made up of NHS services. However, there is a percentage difference to England, Wales and Scotland based on what percentage your NHS income is.

Be aware there are strict guidelines on claiming. If you miss the deadlines stated in the payment statements, you will not receive the associated renumeration, For instance in England and Wales if you submit after the allowable three months after the date the demand notice falls due, you will be refused payment.

BDA Extra and Expert members can call the BDA for more guidance on NHS Entitlements. Alternatively, all information relating to non-domestic rates, including eligibility and how to claim, is contained in your country's payment statements.

Northern Ireland: See page 79 of the statement of Renumeration: http://www. hscbusiness.hscni.net/pdf/STATEMENT\%20 OF\%20DENTAL\%2OREMUNERATION\%20 2017-18.pdf.

England and Wales: See page 38 of the Statement of Financial Entitlements: https://www.nhsbsa.nhs.uk/sites/default/ files/2017-04/GDS_SFE_2013.pdf.

Scotland: See page 103 of the Dental Renumeration Amendment: https://www.sehd.scot.nhs.uk/pca/ DentalRemunAmendment91.pdf.

https://doi.org/10.1038/s41404-020-0304-0 